\title{
E.K. PEKARSKY'S DICTIONARY OF THE YAKUT LANGUAGE AS A KIND OF SPECIAL SUPERTEXT
}

\author{
O DICIONÁRIO DA LÍNGUA YAKUT DE E.K. PEKARSKY COMO UMA ESPÉCIE DE \\ SUPERTEXTO ESPECIAL
}

\section{DICCIONARIO DE E.K. PEKARSKY DEL LENGUAJE YAKUT COMO UNA ESPECIE DE SUPERTEXTO ESPECIAL}

Elena Stepanovna RUFOVA ${ }^{1}$

\begin{abstract}
This article studies E.K. Pekarsky's Dictionary of the Yakut language within the scientific problem related to a supertext. Linguistic and literary works consider supertext as a multidimensional, cross-temporal, cross-personal, and polygenre phenomenon within the framework of the interpreted integrity of a number of independent texts; and integrity as a paradigmatic component that is a constitutive part of the supertext. In supertexts, the textual component forms intertextual links and is revealed in the textual concept sphere, and simultaneously forms supertext links, creating a single text space.
\end{abstract}

KEYWORDS: Dictionary. Yakut language. E.K. Pekarsky. Supertext. Text.

RESUMO: Este artigo estuda O Dicionário de E.K. Pekarsky da língua Yakut dentro do problema cientifico relacionado a um supertexto. As obras linguísticas e literárias consideram o supertexto como um fenomeno multidimensional, intertemporal, interpessoal e poligênico dentro da estrutura da integridade interpretada de uma série de textos independentes; e integridade como um componente paradigmático que é uma parte constitutiva do supertexto. Nos supertextos, o componente textual forma elos intertextuais e é revelado na esfera do conceito textual e, simultaneamente, forma elos de supertexto, criando um único espaço de texto.

PALAVRAS-CHAVE: Dicionário. Língua Yakut. E.K. Pekarsky. Supertexto. Texto.

RESUMEN: Este artículo estudia a Diccionario de E.K. Pekarsky del lenguaje Yakut dentro del problema científico relacionado con un supertexto. Las obras lingüísticas y literarias consideran el supertexto como un fenómeno multidimensional, transtemporal, transpersonal y poligénico en el marco de la integridad interpretada de varios textos independientes; y la integridad como componente paradigmático es parte constitutiva del supertexto. En los supertextos, el componente textual forma enlaces intertextuales y se revela en la esfera del concepto textual, y simultáneamente forma enlaces de supertexto, creando un solo espacio de texto.

1 North-Eastern Federal University named after M.K. Ammosov (NEFU), Yakutsk - Russia. Associate Professor. Candidate of Philology. ORCID: https://orcid.org/0000-0002-1276-7087. E-mail: el.rufova@yandex.ru 
PALABRAS CLAVE: Diccionario. Idioma Yakut. E.K. Pekarsky. Supertexto. Texto.

\section{Introduction}

Rethinking historical and social phenomena within changing cultural paradigms and expanding the objects of humanitarian knowledge makes the concept of supertext relevant. Considering the text not only as the highest communicative unit, but also through the prism of its linguoculturological nature is currently acquiring a controversial character.

Toporov (2013) dealt with the problem of supertext in the literary study of the Petersburg text of Russian literature with its semantic integrity as the main specific feature of the supertext. "In this sense, cross-genre, cross-temporality, and cross-personality help to recognize a certain text as a single one according to the interpretation accepted here" (p. 26).

Kupina and Bitenskaya (1994, p. 215) note that, "supertext is a total of statements and texts, limited temporally and locally, combined meaningfully and situationally, and characterized by an integral modal attitude". In the studies by Bolotnova (1999), Litvinenko (2008) and others, the principle of integrity, contextuality, and centralization of actualized meanings are identified as the main features of supertext. Thus, modern literary criticism and linguistics consider the integral nature of supertext in the cultural and linguistic space (GENERALOVA, 2018).

Summarizing the studies of modern linguists on the scientific problems of supertext, one can imagine it as independent texts united by a certain semantic unity, which in their totality can create a single linguocultural space, a component of the text concept sphere. Supertext as a verbal and sense bearing phenomenon undergoes many interpretations and variations, but the principle of integrity and contextuality can be singled out as a fundamental component.

Following Belyakova (2019), this article considers the interpretation of the materials of E.K. Pekarsky's Dictionary of the Yakut language as a kind of special supertext. The dictionary as an information system is determined by its structuring, information content, integrity, and practical significance. 


\title{
Methods and methodology
}

The methodological basis of this research is the textocentric and anthropocentric approaches to the study of the supertext phenomenon and the study of the historical source within the cognitive history framework. This scientific approach is based on

\begin{abstract}
an understanding of the historical and anthropological foundations of human activity, a person's ability to create an intellectual product through his purposeful and conscious activity. An intellectual product (or thing) is personal in origin, social in functions and has universal human value as an information resource (RUSINA, 2015, p. 125).
\end{abstract}

The textocentric approach addresses the text as an integral system with certain textual categories and properties (I.R. Galperin, E.A. Goncharova, G.A. Zolotova, I.I. Kovtunova, E.V. Paducheva, I. Ya. Chernukhina and others).

According to the anthropocentric approach, interpretation of the text is made in terms of its creation and perception. This approach allows considering the communicative and pragmatic nature of the text as a multifaceted phenomenon with certain goals and methods for influencing the addressee. In this aspect, the text is studied as a set of created elements with relations formed between them. At the same time, text formation is understood as a semiotic process of text development (Van Dyck, T. Vinograd, Yu.N. Karaulov, T.M. Nikolaeva, B.A. Serebryannikov etc.).

General scientific research methods such as description, semantic-stylistic, contextological and structural analysis were used in the study, which allow identifying the problems of semantic transformation within the framework of the supertext as a phenomenon and recording the text in the cultural conceptosphere space.

The Dictionary of the Yakut language by the soviet linguist E.K. Pekarsky and his work were dealt with more than once in various studies. E.I. Okoneshnikov's fundamental research "E.K. Pekarsky as a lexicographer" (1979) is among them. After that, the author will still produce several written works and hold confereces on the scientific heritage of Eduard Karlovich Pekarsky, the honorary academic of the Russian Academy of Sciences (RUFOVA, 2020).

The fundamental works of O.N. Boettlingk, P.A. Oyunsky, E.I. Ubryatova, L.N. Kharitonova, N. D. Dyachkovsky, P.A. Sleptsov, N.E. Petrov, G.G. Filippov, E.I. Okoneshnikov, S.A. Ivanov, I.E. Alekseev, L.A. Afanasyev, M.P. Alekseev in Yakut linguistics served as the methodological basis for the lexicographic part of this study. 


\section{Results}

The Dictionary of the Yakut language is initially of a pragmatic nature, as the compiler evidenced in the preface (PEKARSKY, 1899). In 1881, Eduard Karlovich Pekarsky was sent into exile in the Boturusky region in Yakutia. He states that upon arrival he immediately asked for an assistant who would help in speaking the Yakut language with locals (OKONESHNIKOV, 2008). Thus, the study of the Yakut language was initially determined by social and daily factors, and later by the compiler's research interest, who wanted to show the rich linguistic potential of the Yakut language.

In 1894-1896, E.K. Pekarsky participated in the Yakutsk Siberian expedition organized by the East Siberian Department of the Russian Geographical Society and financed by I.M. Sibiryakov, Russian philanthropist and owner of gold mines. The main purpose of the expedition was to investigate the natural resources of the Russian Empire. Another task was to study socio-cultural resources, namely, the local people's life and culture. According to the expedition program, the findings were supposed to be published in several volumes at the expense of I.M. Sibiryakov's personal funds, but because of his illness, only some materials were published in the printed editions of the East Siberian Department (2020). It is believed that it was I.M. Sibiryakov's personal initiative to publish a dictionary of the Yakut language. Thus, the first volume of the Dictionary of the Yakut Language was published by the Yakut regional printing house after the expedition at I.M. Sibiryakov's expense (MONASTYREV et al., 2021). Subsequent volumes of the dictionary were published by the Publishing House of the Russian Academy of Sciences.

In 1907-1930, 13 volumes of the dictionary were published under the title Dictionary of the Yakut Language, compiled by E.K. Pekarsky involving the Archpriests D.D. Popov and V. M. Ionov in the publishing house of the Russian Academy of Sciences in St. Petersburg, including the first issue of 1899 republished. This dictionary is still relevant. It is a fundamental work in Turkic studies and one of the largest dictionaries related to the Turkic languages (25 thousand words). This fact only underlines the historical significance of the dictionary, revealing its social nature.

The second half of the 19th century in the history of Yakut lexicography is the initial stage in developing a dictionary text. During this period, the task of the lexicographic text was precisely to convey the lexical meaning of a word, so bilingual translation dictionaries appeared as the first dictionaries. In this perspective, E.K. Pekarsky's Dictionary of the Yakut Language, perform the main function of interpretation of the word meaning and also performs 
an educational function, and in the general historical perspective also the function of recording, preserving, and transmitting a large amount of linguistic material.

The dictionary begins with a preface by E.K. Pekarsky, in which the author reveals in detail the history of the dictionary creation, indicates the specific circumstances and names of everyone who took part in the dictionary compiling and publication. Significant in this regard is the mention of the motives and the main purpose of creating this dictionary. The author emphasizes the scientific importance and the need to collect and structure the language material not only to expand and supplement the materials regarding the Yakut language available at that time but believes that it will be a valuable material for researchers to understand the Yakut people's "soul". Also in a separate article, E.K. Pekarsky explains the alphabet used in the dictionary. Let us note that that historical stage is characterized as the beginning of the birth of the Yakut language writing. There were several variants of alphabets, mainly based on the Russian language writing, but the generally accepted alphabet of the Yakut language was not determined. E.K. Pekarsky creates certain signs, based on Otto von Böhtlingk's alphabet, to convey the phonetic features of the Yakut language, which makes an invaluable contribution to the origin and formation of the Yakut writing. A rather impressive list of sources (94 works) and manuals ( 25 works), and most likely everything that existed at that historical period and was used in compiling the dictionary, highlights the fundamental nature of this work. They included works on ethnography (V.L. Seroshevsky), religion (V.F. Troshchansky, V.L. Priklonsky, and N.P. Pripuzov), folklore and literature (I.A. Khudyakov, N. Popov etc.), the first handwritten dictionaries and works on the Yakut language (P.F. Poryadin, M.A. Natanson, A.S. Orlov, D. Khitrov etc.) and the first translations of church literature in the Yakut language.

In the context of the dictionary typology, it is difficult to attribute it to any specific type according to L.V. Shcherba (2004), but all the lexicographic features of all types of dictionaries are highlighted. Yakut researchers V.D. Monastyrev, N.N. Vasiliev, I.V. Ammosova refer the Dictionary of the Yakut language by E.K. Pekarsky in the YakutRussian translation-encyclopedic dictionaries (MONASTYREV; VASILIEVA; AMMOSOVA, 2021). This dictionary vocabulary includes interjections, common words, dialect words, terminology, phraseological units, etymological comparisons, regional and cultural realities etc. Most researchers emphasize its value due to the folklore material represented by the vocabulary of Olonkho, Yakut heroic epos. The fundamental significance of the dictionary as a scientific work is enhanced owing to the collection and presentation of the multifaceted and diverse Yakut language vocabulary. The dictionary vocabulary is quite 
voluminous both in terms of thematic variety and stylistic features. From this perspective, a certain degree of coherence can be distinguished, which is inherent in texts of this nature, because dictionary entries, with all their complete character, can perform their function only in their aggregate unity. Such structuring and the alphabetical order of dictionary entries characterize completeness, a marked end, which makes it possible to determine E.K. Pekarsky's dictionary as a conditionally closed supertext according to N.A. Kupina and G.V. Bitenskaya's typology of supertexts.

The undoubted fact is that this dictionary has integrity and is determined by the totality of all its elements, which include both dictionary entries and, in fact, editions. The lexicographic nature determines the structuring and systematization of the selected linguistic material.

The dictionary entry of the author's dictionary as an independent type of text has a textual character. A dictionary entry in E.K. Pekarsky's dictionary is characterized by special thematic and functional aspects, built in accordance with the obligatory structural and compositional elements. Such a generalized model for constructing a dictionary entry is determined by the text type model and establishes its textual typological features. Dictionary entries are characterized by semantic and structural completeness. At the same time, this type of text exists only in the aggregate of the set, which, in fact, constitutes the dictionary integrity. Thus, the integrity of E.K. Pekarsky's dictionary is determined by its composition pattern, in which there are intra-textual intertextuality and the integrity of the relationships between dictionary entries and issues within the entire dictionary. The author's preface as another separate independent textual element strengthens semantic integrity, reflecting the main idea and purpose of creating a dictionary of the Yakut language.

In terms of the "addresser and addressee", the dictionary as a kind of special supertext is determined by its own specifics. "With regard to a dictionary (any), one can talk about two levels of the authorship" (BELYAKOVA, 2019), the first level is represented by the native speaker, that is, a collective author, a representative of the cultural and linguistic space. The second level is represented by the compiler, who, in fact, forms the linguistic material, giving the text a certain form and structure, a definite practical task, and communicative orientation. It is also possible to show the addresser on two levels like the author. The first level is where the addresser is at the time of creation, perhaps then, in a narrow sense, linguists, exiles in Yakutia, expedition participants, and local intellectuals. The second level has a broader framework, especially in the context of studying E.K. Pekarsky's dictionary as a historical 
and linguistic monument, one of the fundamental works in Turkic studies and the largest dictionary.

Thus, the cross-personality of this dictionary is realized, emphasizing the unity of the interpretation of the cultural-linguistic space, reinforced by cross-temporality and the local factor as structure-forming features of the supertext as a phenomenon.

\section{Discussion}

This dictionary has not only linguistic, but also historical and cultural significance, because the dictionary reflects the linguistic picture of the world and reveals the historical features of a certain period. Moreover, the dialectical unity of the objective and the subjective inherent in the bilingual encyclopedic dictionary is transparently defined and highlighted. The objectivity of E.K. Pekarsky's Dictionary of the Yakut Language lies in the external manifestation of the form as a multivolume dictionary, but at the same time it also includes the subjective, that is, it reflects a person with his consciousness and needs.

In this article, the dictionary by E.K. Pekarsky is treated as a special kind of supertext. The study of the author's vocabulary in terms of this issue allows expanding the textual conceptual space. Dictionary entries, acting as a source of linguocultural information, manifest the conceptual sphere of the language. In supertexts, the textual component forms intertextual links, revealing in the textual conceptual sphere, and simultaneously forms supertext links, forming a single text space.

This vision of the text as an independent, unified and integral linguocultural space is considered in an inextricable connection with the author's personality and historical reality, which can be traced in many fundamental philological works. Thus, the issue of the concept of supertext can be regarded from the point of view of the internal form of a word and a work (A.A. Potebnya); "an unconsciously formed convention” (A.N. Veselovsky); cultural and linguistic space of stable collections of motives and characters (V. Ya. Propp), and basic elements of the plot (V.V. Vinogradov).

The dictionary as an information system is determined by its structuring, information value, integrity, and practical significance, which is characterized by openness, first, at the level of the subject-object text arrangement. 


\section{Conclusion}

To sum up, E.K. Pekarsky's Dictionary of the Yakut Language represented in this article can be regarded as a special kind of supertext. Structurally, the dictionary consists of texts of a certain type - dictionary entries, and the dictionary editions. This dictionary is characterized by coherence reflected in spatial and temporal perspectives. The supertext particularity is also manifested in the cross-personality of this dictionary reflected not only in the personality of the compiler-author and his numerous consultants, but also demonstrating the generalized personality of the native speaker of the Yakut language and Yakut culture. The study revealed another feature specific to this type of supertext. These are the relations of the collective addresser and addressee and the integrity of perception and their dual nature. So, based on the mentioned criteria, we can assume that E.K. Pekarsky's Dictionary of the Yakut Language, which combines the features of translation and encyclopedic dictionaries, refers to a conditional closed supertext possessing a significant degree of structural and thematic certainty.

ACKNOWLEDGMENTS: The paper has been funded by Russian Foundation for Basic Research according to the research project № 19-012-00467a.

\section{REFERENCES}

BELYAKOVA, S. M. Dialect dictionary as a kind of supertext. Issues of Lexicography, v. 15, p. 5-16, 2019.

BOLOTNOVA, N. S. Fundamentals of text theory: a guide for teachers and students of philology at the Pedagogical University. Tomsk: Tomsk State Pedagogical University Publishing House, 1999.

CHEN, W. Towards a Discourse Approach to Critical Lexicography. International Journal of Lexicography, v. 32, n. 3, p. 362-388. 2019.

GENERALOVA, E. V. Russian historical lexicography: text-centric and word-centric approaches. Issues of Lexicography, v. 13, p. 8-22, 2018. DOI: 10.17223/22274200/13/1

GRIGORIEVA, V. S. Discourse as an element of the communicative process:

pragmalinguistic and cognitive aspects. Tambov: Tambov State Technical University Publishing House, 2007.

ISHEGULOVA, A. M. Academic dictionary of the Bashkir language, Issues of Lexicography, v. 14, p. 69-79, 2018. DOI: 10.17223/22274200/14/4. 
JACKSON, H. Lexicography: An introduction. London; New York: Routledge, 2002.

KRUGLOV, V. M. On the publication of unknown pages of the academic Dictionary of the Russian Language (1930-1936): general characteristics of archival material, publication rules, sample fragment. Proceedings of the Institute for Linguistic Research, v. 14, n. 1, p. 401$440,2018$.

KUPINA, N. A.; BITENSKAYA, G. V. Supertext and its varieties. Man - Text - Culture. Yekaterinburg, 1994.

LITVINENKO, T. E. Intertext in the context of linguistics and general theory of language. Irkutsk: IGLU, 2008.

LOSHAKOV, A. G. Supertext: the problem of integrity, principles of modeling. Kirov: Moscow State Pedagogical University, 2008.

MONASTYREV, V. D.; VASILIEVA, N. N.; AMMOSOVA I. V. Big explanatory dictionary of the Yakut language: a new achievement of the Yakut lexicography. Issues of Lexicography, v. 19, p. 92-108, 2021. DOI: 10.17223/22274200/19/5

NORMAN, G. Description and prescription in dictionaries of scientific terms. International Journal of Lexicography, v. 15, n. 4, p. 259-276, 2002.

OKONESHNIKOV, E. I. Yakut phenomenon of E.K. Pekarsky. Yakutsk. 2008.

PEKARSKY, E. K. Dictionary of the Yakut language. Proceedings of the Yakut expedition at I.M. Sibiryakov's expence (1894-1896). Yakutsk: Yakutsk Regional Printing House, 1899.

PEREDRIENKO, T. Y.; BALANDINA, E. S. Representation of the concepts "obshchestvo (society)" and "society" in lexicographic discourse. Issues of Lexicography, v. 17, p. 51-73, 2020. DOI: $10.17223 / 22274200 / 17 / 3$

PETROVA, Z. Y.; REBETSKAYA, N. A.; FATEEVA, N. A. The project of creating an information retrieval system based on the Dictionary of Metaphors and Comparisons of Russian literature of the 19-21centuries. Modern problems of author's lexicography: collection of scientific articles. Moscow: Akvilon, 2018.

PRIEMYSHEVA, M. N.; STUKOVA, E. G. Academic Dictionary of the Russian Language edited by Academician N.S. Derzhavin (1929-1937) in the history of Russian explanatory lexicography. Issues of Lexicography, v. 17, p. 195-212, 2020. DOI:

$10.17223 / 22274200 / 17 / 10$

PRIEMYSHEVA, M. N.; STUKOVA, E. G. At the origins of the Dictionary of the Modern Russian Literary Language: from the history of academic explanatory lexicography of the late $30 \mathrm{ies}$ in the 20th century. Russian academic lexicography: current state and development prospects: collection of scientific articles based on materials of the International Scientific conf. dedicated to the 70th anniversary of the publication of the first volume of the academic Dictionary of the Modern Russian Literary Language. St. Petersburg: ILI RAN, 2018. 
RUFOVA, E. S. Dictionary of the Yakut language by E.K. Pekarsky as a lexicographic monument. Society: philosophy, history, culture, v. 11, n. 79, p. 74-76, 2020. DOI $10.24158 /$ fik.2020.11.12

RUSINA, Y. A. Source study methodology. Yekaterinburg: Ural University Publishing House. 2015.

SERGEEV, M. L.; FIVEYSKAYA, E. A. On the problem of etymology in explanatory lexicography (based on the Dictionary of the Russian language of the 21 st century). Issues of Lexicography, v. 17, p. 74-89, 2020. DOI: 10.17223/22274200/17/4

SERGEEV, M. L.; FIVEYSKAYA, E. A. The use of information about the etymology of the word in the lexicographic description (based on the latest borrowed vocabulary). Russian language: Historical destinies and the present. In: INTERNATIONAL CONGRESS OF RESEARCHERS OF THE RUSSIAN LANGUAGE, 2019, 6., Moscow. Proceedings [...]. Moscow: M.V. Lomonosov Moscow State University, Faculty of Philology, March 20-23, 2019.

SHCHERBA, L. V. Experience of the general theory of lexicography. Language system and speech activity. Moscow: Editorial URSS, 2004.

SHESTAKOVA, L.L., KULEVA, A.S. On the experience of work on the seventh volume of Words in the Language of Russian Poetry of the XX Century. Modern problems of author's lexicography: collection of scientific articles. Moscow: Akvilon, 2018.

SIBIRYAKOV'S expedition. National Archives of the Republic of Sakha (Yakutia). Available in: http://archivesakha.ru/?page_id=5854. Access: 19 Oct. 2020.

SKLYAREVSKAYA, G. N. General information about the dictionary. Dictionary of the Russian language of the 21st century: Project. St. Petersburg: A.I. Herzen Russian State Pedagogical University Publishing House, 2019.

SOKOLOVA, O. V. From avant-garde to neo-avant-garde: language, subjectivity, cultural transfers. Moscow: Cultural revolution, 2019.

TOPOROV, V. N. Petersburg Text of Russian Literature: selected works. St. Petersburg: Art, 2003.

UKHOVA, L. V. "Promotional text": concept, features, functions. Verkhnevolzhsk Philological Bulletin, v. 3, p. 71-82, 2018.

YAGAFAROVA, G. N. The newest Turkic lexicography (about a new type of explanatory dictionaries). North-Eastern Humanitarian Bulletin, v. 1, n. 26, p. 77-84, 2019. DOI 10.25693/SVGV.2019.01.26.010

YURINA, E. A.; BALDOVA, A. V. Dictionary of Russian Food Metaphor as a reflection of a fragment of the figurative system of language and the prospects for computer multilingual lexicography. Russian academic lexicography: current state and development prospects: collection of scientific articles based on materials from International Scientific 
Conf. dedicated to the 70th anniversary of the publication of the first volume of the academic Dictionary of the Modern Russian Literary Language. St. Petersburg: Nestor-istoriya, 2018.

ZYKOVA, I. V. The conceptual framework of culture and phraseology: theory and methods of linguoculturological study. Moscow: LENAND, 2015.

ZYKOVA, I. V. The metalanguage of cultural linguistics: constants and variants. Moscow: Gnosis, 2017.

\section{How to reference this article}

RUFOVA, E. S. E.K. Pekarsky's dictionary of the Yakut language as a kind of special supertext. Revista Entrelinguas, Araraquara, v. 7, n. 00, e021030, 2021. e-ISSN:2447-3529. DOI: https://doi.org/10.29051/el.v7i00.15183

Submitted: $14 / 05 / 2021$

Required revisions: $26 / 05 / 2021$

Approved: 05/06/2021

Published: 14/06/2021 